\title{
Impact of Online Business Model on Indian Economy
}

\author{
Dr. Gajanan Gopalrao Babde \\ Asistant Professor, Department of Commerce, Nutan Adarsh Arts, Commerce and M. H. \\ Wegad Science College Umred, Dist - Nagpur, Mo. No. 9822497119, \\ Email Id-gajananbabde03@gmail.com
}

\begin{abstract}
:
Indian economy is fastest growing economy in whole world and the largest market in whole world. In context to this there is a wide scope for development of offline and online market. Since last 15 years use of internet and smart phone are increased and playingkey role in development of e-commerce market. Essential infrastructural features like convenient payment method, cash on delivery, fast delivery of product, costumer oriented attractive schemes, easy method to return product etc. play vital role in development in ecommerce. Government's different policies like Digital India and Start-up also give motivation to people for online shopping. In India, the online business market was 3.9 billion US\$, which increase and reach to 12.6 billion US\$ in 2013 and 38.5 billion US\$ in 2017. This paper focuses on the impact of online business model on the Indian economy.
\end{abstract}

Keywords: online business, e-commerce, Indian economy

\section{Introduction}

Indian economy is one of the speedy increasing economies in whole world. In India approx $17.00 \%$ population of whole world is living. So, there is a huge market for consumer products. Since last two decades increase in middle class income group have been seen. Besides this, due to cheaper smart phones and low internet rate there is huge increase in the users of smart phones and internet, which gives important contribution in development of ecommerce market. Different initiatives taken by Government and launching of different policies like Digital India and Start-up plays vital role in development of e-commerce. There was market for ecommerce in 2009 was only 3.9 billion US\$ which grow up and reach up to 12.6 billion US\$ and 38.5 billion US\$ in the year 2013 and 2017 respectively. According to the researchers, till 2026 there will be 200 billion US\$ market of e-commerce and it will be $4.00 \%$ share of GDP of country.

Electronic commerce is a one of the most important part of the information technology revolution which became widely used in the world trade in general and Indian economy in particular. E-Commerce stands for electronic Commerce which means dealing in goods and services through the electronic media and internet. Now a days there is a tremendous growing rate of awareness among businessman's about various opportunities offered by E-commercecommerce business is not only connected to urban area but also it is widely connected in 
villages too. India is showing the increase of smartphones and internets are mostly contributing to the growth of e-commerce. Convenient payment process, speedy delivery of product, high discount, customer friendly policies and easy returns are driving more customers towards online shopping.

Definition Of E-Commerce "Ecommerce, also known as electronic commerce or internet commerce, refers to the buying and selling of goods or services using the internet, and the transfer of money and data to execute these transactions." Ecommerce is often used to refer to the sale of physical products online, but it can also describe any kind of commercial transaction that is facilitated through the internet.

\section{Objectives:}

- To study the online business model.

- To analyse various factors involved in online business model

- To study the impact of online business model on Indian Economy

\section{Hypothesis}

$\mathrm{H}_{0}$ : There is no significant impact of online business model on Indian Economy.

$\mathrm{H}_{1}$ : There is a significant impact of online business model on Indian Economy.

\section{Online Business Model}

E-Commerce is a growing sector in India. Just like the growth of IT industry in India through the 1990s, the 2010s will be remembered for the growth in the E-Commerce industry. In its present state the contribution of E-Commerce to GDP is around $0.2 \%$ which is expected to grow 15 times to around $2.5 \%$ by 2030 .

The impact is so huge that the present wave of de-monetisation could have not been thought if E-Commerce did not exist. E-Commerce to a large extent helped absorb its shock as well as gained the maximum out of it as well.

By 2030 the contribution to GDP by E-Commerce is expected to reach to around 300 Billion Dollars which is around 20 Billion Dollars in its present state. 


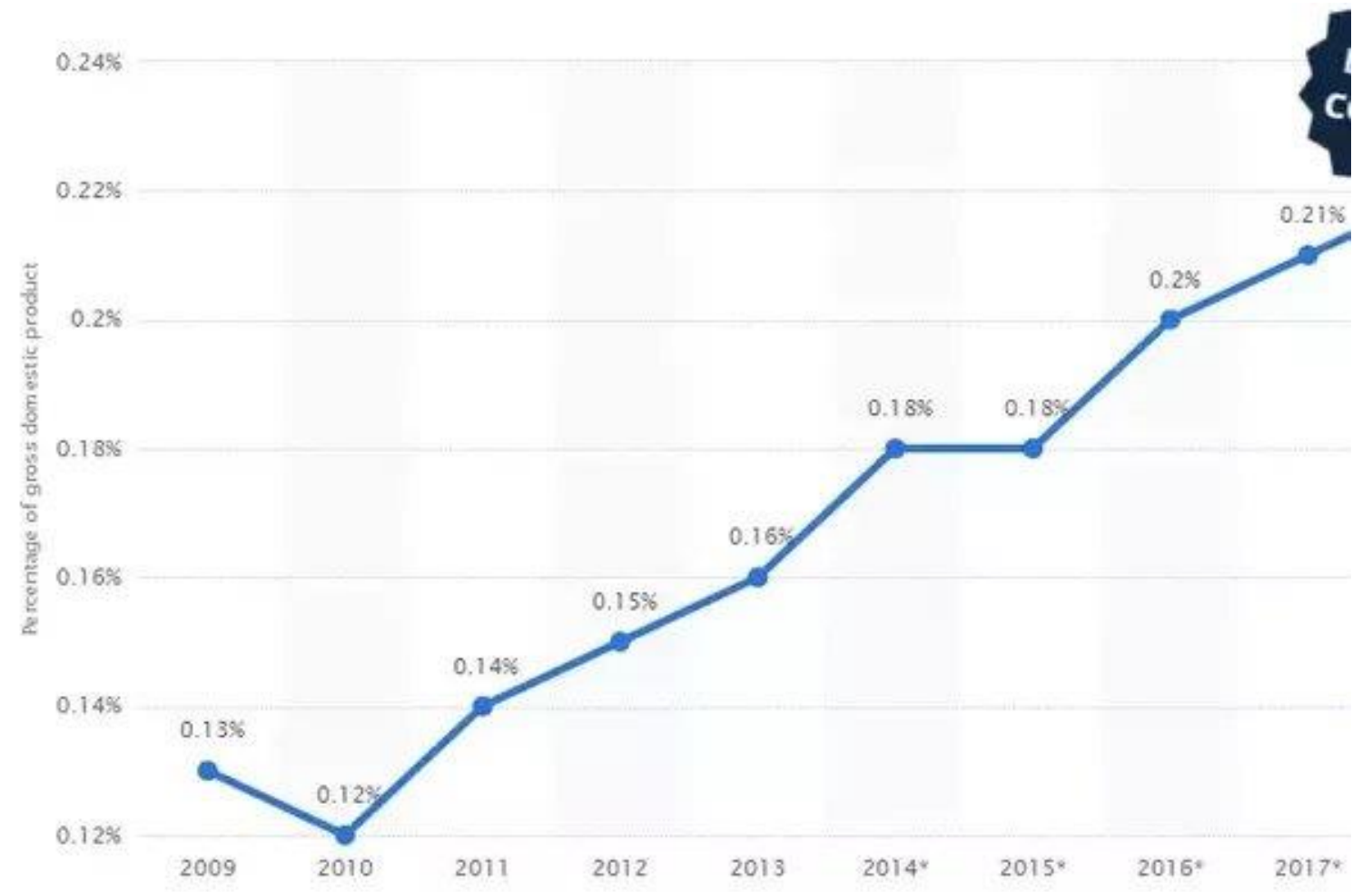

Total e-Commerce size (\$ Ballion)

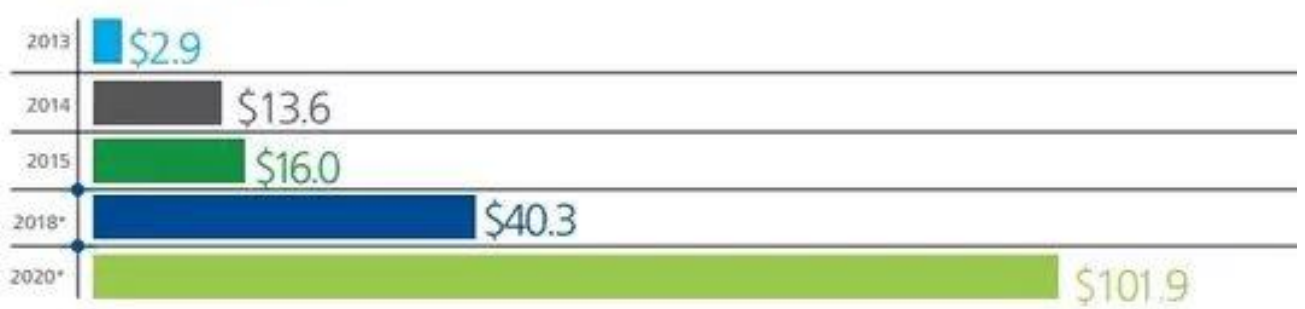

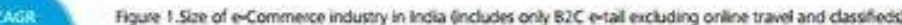

340\% A $6 x$ growth over 5 years is envisaged for e-Commerce driven by foctors hike new-age technology. comvenience, higher adoption rates and larger reach

After the initial wave of B2C E-Commerce, the B2B sector is gaining a lot of traction. 95\% of the business in the B2B sector is still unroganised and E-Commerce will help organise by use of technology and other support functions.

The impact of E-Commerce industry are still in very nascent stage but are visible. The impact at the moment can be seen in the following sectors:-

1. Technology- One of the major drivers of technology will be E-Commerce industry and vice versa. We are seeing new age technological solutions(AI/Machine Learning) being taken up to solve the business problems to bring commerce to everyone digitally. This is seen in both B2C and B2B sector. Investment into technology sector is happening to drive growth in the E-Commerce domain. 
2. Logistics- Logistics industry is both a bottleneck and a driver for e-commerce industry. For the same we see how last mile and inter-city logistics solutions have come up to digitally connect the different stakeholders across the country. The Uber model of moving passengers is implemented in some form or the other in the logistic sector. The growth of E-Commerce will drive innovation in the logistic sector to make the products available to the end user.

3. Travel- At the moment $70 \%$ of the contribution to E-Commerce comes from the travel sector which includes the online ticket bookings to other travel arrangements. This has made the market competitive by bringing all players on the same platform and has also given consumer more options. Travel industry will be earliest adopters to become completely digitised and that is thanks to E-Commerce.

4. Education- One of the industries to have the most profound impact of E-Commerce is the education. The ability of E-Commerce to provide quality education to everyone is immense. India will have one of the biggest set of youth population and hence the scope for education sector to be the biggest achievers because of E-Commerce is sure.

5. Etail- The flag bearers of the E-commerce wave have been the various E-Retail commerce platforms. Etail sector is projected to contribute to around 3\% of the total Retail sells by 2020 and is at present around 1\%. This wave is seen in both $\mathrm{B} 2 \mathrm{C}$ and $\mathrm{C} 2 \mathrm{C}$ model and is bound to grow further. This is not only for goods but also has captured the food sector.

6. Other Industries- The way of working in the Real Estate sector is already seeing the change because of the E-Commerce industry. This will change further with all property related transactions coming online and getting closed online as well. Banking sector is benefiting as well with reduced operations cost of online transactions. E-Commerce in health care has brought health related solutions to the urban India and will further penetrate deep into Tier I and Tier II cities.

7. Support Industries- There are various support industries which have developed because of E-Commerce. These are digital advertising, analytics, payment gateways etc.. These will become billion dollars sectors as E-Commerce grows exponentially.

Besides the impact to these industries, E-Commerce is helping make the market more competitive, driving better customer experience and driving accessibility of goods to all. ECommerce is also bringing transactions online which makes the system more transparent and to an extent may further drive technological adoption. This will also help in driving corruption levels down with everything coming online. The impact are profound and will evolve with time.

\section{Online Business Model on Indian Economy}

E-commerce in India is growing not just because of the internet penetration is increasing but also due to the favourable ecosystem developed by the market. E-commerce and electronic applications in automation has brought in tremendous growth in India. E-commerce is 
connecting rural India for the business hence develop village economy. According to NATIONAL REPORT OF E-COMMERCE DEVELOPMENT IN INDIA, it was clearly stated that there is increase in internet penetration in India to very large extent. Internet user increases to 429.23 Million in 2017 which is expected to take a huge upward trend to 829 million in 2021, which will thus help internet economy of India to grow significantly.

With the increase of digital penetration and increase of internet penetration in Indian context, it was thus needed to link between the growth and impact of ecommerce in context of Indian scenario." With the increase in digital buyer, it was quite clear the internet penetration will thus also ultimately rise to certain extent, also as we have studied in earlier paper that mcommerce has also increased significantly thus lead to growth in m-commerce. Thus, with the advancement of technology and increase in share of smartphone and internet operators it was quite clear that internet penetration was much needed to make a more significant impact on the Indian market.

Table 1 : Impact of online business model on Indian Economy

Total Respondents : 50

\begin{tabular}{|l|l|l|l|l|}
\hline $\begin{array}{l}\text { Strongly } \\
\text { Agree }\end{array}$ & Agree & Neutral & Disagree & $\begin{array}{l}\text { Strongly } \\
\text { Disagree }\end{array}$ \\
\hline 9 & 18 & 11 & 7 & 5 \\
\hline
\end{tabular}

Graph 1: Impact of online business model on Indian Economy

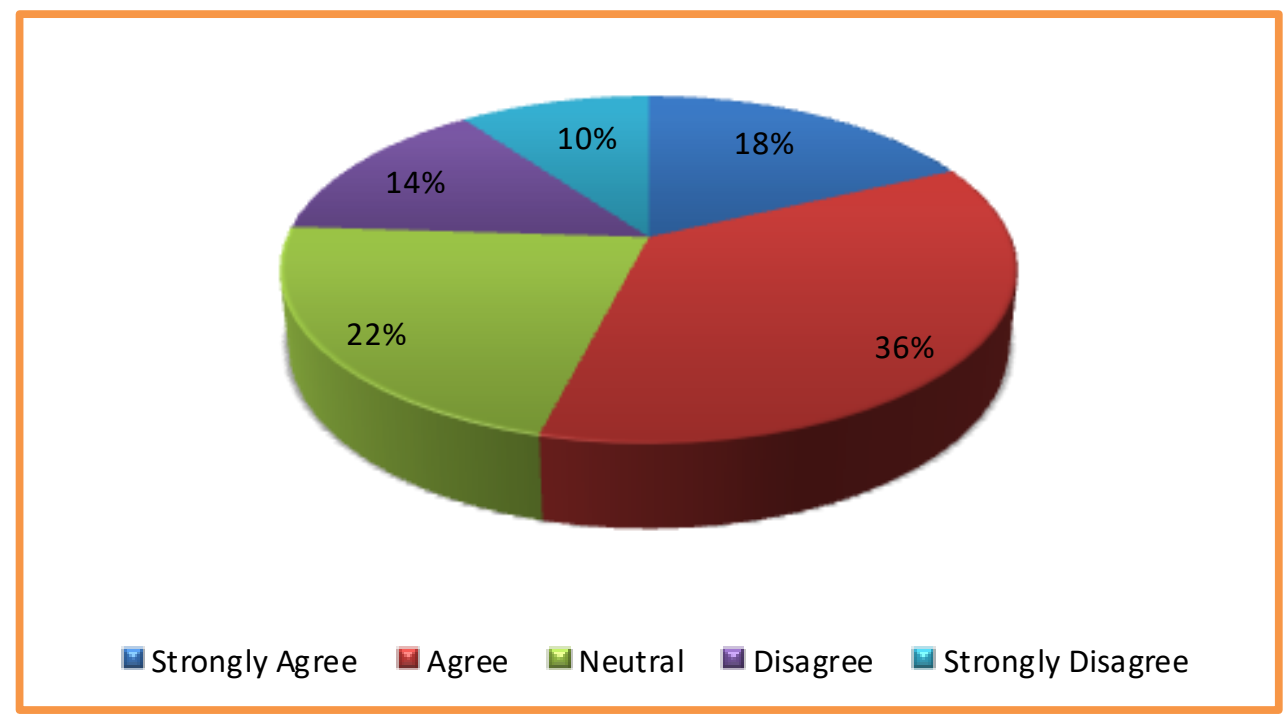

From the above graph; it is found that out of 50 respondents $18 \%$ are strongly agree with the statement 'Impact of online business model on Indian Economy'; 36\% agree with the statement, $22 \%$ are neutral with the statement, $14 \%$ are disagree with the statement while $10 \%$ are strongly disagree with the statement.

That means majority of the respondents feels that online business model is significantly impacting on the Indian Economy. 


\section{Hypothesis Testing:}

Hypothesis assumed during this research have been the proposition as statements about the observable phenomena in this study that may be judged as true or false. As a declarative statement about the two or more variables, the hypotheses stated were of the tentative and notional nature. The Hypotheses assumed during the study are :

$\mathrm{H}_{0}$ : There is no significant impact of online business model on Indian Economy.

$\mathrm{H}_{1}$ : There is a significant impact of online business model on Indian Economy.

The hypotheses stated above have been formed after carefully analyzing the research objectives and the problem definition. In a nutshell, the hypothesis assumed during this research study has been the best expression of the research objective in the form of a wellformed and testable statement which could be disproved or proved by empirical data.

This hypothesis regarding impact of online business model on Indian Economy through the One Sample t-test using statistical software SPSS.

\section{One-Sample Statistics}

\begin{tabular}{|l|l|l|lr|}
\hline $\mathrm{N}$ & Mean & Std. Deviation & $\begin{array}{l}\text { Std. } \\
\text { Mean }\end{array}$ & Error \\
\hline 49 & 2.1802 & 1.8360 & .03261 & \\
\hline
\end{tabular}

\section{One-Sample Test}

\begin{tabular}{|c|c|c|c|c|c|}
\hline \multicolumn{6}{|c|}{ Test Value $=2.68$} \\
\hline \multirow[t]{2}{*}{$\mathrm{t}$} & \multirow[t]{2}{*}{$\mathrm{df}$} & \multirow[t]{2}{*}{ Sig. (2-tailed) } & \multirow[t]{2}{*}{$\begin{array}{l}\text { Mean } \\
\text { Difference }\end{array}$} & \multicolumn{2}{|c|}{$\begin{array}{l}95 \% \text { Confidence Interval of } \\
\text { the Difference }\end{array}$} \\
\hline & & & & Lower & Upper \\
\hline .014 & 49 & .023 & .00045 & -.0521 & .0598 \\
\hline
\end{tabular}

To test this hypothesis; a Likert scale is used. Response of 50 member respondents are recorded and inputted in the SPSS software. The mean value generated is 2.18 and Standard Deviation is 1.84 . The test value is set as 5 as Likert scale is five level scale to record the responses. From the above One Sample t-test hypothesis is significant i.e. 0.023. So the NULL hypothesis is rejected and the alternate hypothesis 'There is a significant impact of online business model on Indian Economy' is accepted.

\section{Conclusion}

Currently online businesses has become an integral part of everyday. Online business model ie.e.e-commerce is emerging as an important tool to certify exploding growth of Indian economy. With a speedily growing internet penetration e-commerce offers an attractive option for the retailers to expand. To achieve this, there should be more investments in supporting infrastructure and innovative and game changing business models in India. Ecommerce is also showing a tremendous growth in promotion of global business wiping out the barriers of boundaries between nations. It is also an integral part in GDP contribution. Imports of goods are also increasing through ecommerce which will benefit various sections 
of society in terms of knowledge, skills, technological advancement, and improved ways of marketing as well as employment. Digital marketing is also growing at faster pace as it's fast, cost effective and easy. According to the hypothesis tested; it is found that there is a significant impact of online business model on Indian Economy.

\section{References:}

- BhargabKalita. Impact of E-commerce on Indian Economy, ICEIS 2016.

- Bimal, Dr.Anjum, \&Tiwari, Rajesh, (2011), 'Economic and Social impact of E-Commerce', CFA International journal of computing and corporate research, Vol. 1(3):2249-054X

- BCG \& IAMAI (2015). India @ Digital Bharat. Creating a \$200 Billion Internet Economy. Mumbai: The Boston Consulting Group

- OECD. ICT Key Indicators. Information Technology Outlook. 2010. (35) IMF, World Economic Outlook, 2006/2011.

- MalhotraBhavya, E-Business: Issues \& Challenges in Indian Perspective, Global Journal of Business Management and Information Technology, ISSN 2278-3679 Volume 4, Number 1 (20)

- https://www.iosrjournals.org/iosr-jbm/papers/Vol20-issue5/Version-6/H2005065971.pdf

- http://italiaindia.com/images/uploads/pdf/april-2016-e-commerce-in-india.pdf

- India: B2C e-commerce as percentage of GDP 2009-2018| Statistic

- http://www.pwc.in/assets/pdfs/publications/2015/ecommerce-in-india-acceleratinggrowth.pdf

- https://www.quora.com/How-does-e-commerce-affect-the-economic-development-of-India

- http://www.aiirjournal.com/uploads/Articles/2020/10/4741_11.Dr.\%20R.\%20S.\%20Pawar\% 20\&\%20Kalyani\%20Dattatraya\%20Ausekar.pdf 